УДК 636.4.082:575.113(477)

DOI 10.32900/2312-8402-2021-125-30-36

\title{
GENETIC ANALYSIS OF UKRAINIAN LARGE WHITE PIG BREED BY POLYMORPHISMS IN RYR1, ESRI AND PRLR GENES
}

\author{
Oliinychenko Y. K., ph. d., sen. research., \\ https://orcid.org/0000-0002-1000-0683 \\ Rossokha V. I., ph. d., sen. research., \\ https://orcid.org/0000-0002-0978-9349 \\ Boyko O. A., ph. d., sen. research., \\ https://orcid.org/0000-0003-3065-0461 \\ Tur G. N., ph. d., sen. research., \\ Zaderikhina O. A., research., \\ https://orcid.org/0000-0002-8907-4908 \\ Brovko O. V., research. \\ Institute of Animal Science of NAAS
}

\begin{abstract}
Marker-Assisted Selection is getting increasing attention in Ukrainian animal breeding as an effective tool for choosing animals with desirable traits. Identification of molecular markers which are related to major genes is a promising approach for improving economic traits and has to be checked for further gene-trait associations. Single nucleotide polymorphisms are genetic markers that can be associated with production traits. SNP genotyping has to be done additionally for each breed to see if they are polymorphic and have significant associations with certain traits. Among the candidate genes that influence the expression of productive traits, special attention is drawn to RYRI, ESRl and PRLR genes. Gene RYRl is associated with muscle hypertrophy and other meat quality defects in pigs. ESRI and PRLR genes influence reproduction and affect the litter size in pigs.

SNPs RYR1 g.1843 C>T, ESR1 SNP c.1227 C>T and PRLR g. 1789 G>A have been receiving increasing attention as potential markers for improving quality and pig performance traits. This study investigated the allele variants in three genes (RYR1, ESRI and PRLR) in Ukrainian Large White pigs of different inside breed types (ULW-1 and $U L W-2)$. The study was performed on 200 pigs. Genotyping was performed using PCR-RFLP method. SNP RYR1 g.1843 C>T was not polymorphic in ULW-1 and ULW2 inside breed types, when ESR1 SNP c.1227 C>T and PRLR g. $1789 G>A$ were highly polymorphic. SNPs in ESRI and PRLR genes had high PIC and $\chi^{2}$ values which indicates the relevance of further associative studies in $U L W-1$ and $U L W-2$. Informativeness of the genetic markers in ESRI and PRLR genes was optimal for associative studies in Ukrainian Large White pig breed of first and second inside breed type.

\section{Keywords: SNP, RYR1, ESR1, PRLR, PCR-RFLP, Ukrainian Large White} breed.
\end{abstract}

Marker-Assisted Selection (MAS) is an indirect selection method based on association analysis of genomic information with certain phenotypic traits to increase the selection efficiency. MAS aims to use certain gene markers to indicate the presence of desirable gene alleles which can increase the accuracy of identifying superior animals [7].

Applying animal selection by some genes associated with reproductive traits has been recommended to achieve further genetic progress for desired traits. Many genetic markers were proven to be linked with affecting traits of economic importance in live- 
stock. Genetic markers have been identified and mapped during the gene-associated studies in pigs in different breeds. Ukrainian Large White pig breed is one of most numerous breeds and in Ukraine there have been used three inside breed types of the breed. ULW-1 is a maternal type with improved reproductive qualities, ULW-2 - an inside breed type with high fattening qualities and ULW-3 is an intra-breed type with high meaty qualities parameters [10].

Such genes as $R Y R l, E S R l, P R L R$ were identified to impact major breeding traits of pigs. Stress susceptibility has been mapped to the ryanodine receptor $1(R Y R I)$ gene, the ryanodine receptor 1 ( $R Y R 1)$. Single nucleotide polymorphism (SNP) g.1843 $\mathrm{C}>\mathrm{T}$ of $R Y R l$ gene is associated with muscle hypertrophy and other meat quality defects in pigs [4].

Gene ESRI has a crucial role in the female biology of reproduction and affects the litter size. SNP c.1227C> T in ESRl gene is associated with the reproduction of saws and litter size of pigs [1]. Prolactin (lactogenic hormone, PRL) is a peptide hormone that is synthesized in acidophilic cells of the anterior pituitary gland. The main physiological effects are primarily related to the reproduction of animals; the effects of prolactin are realized through prolactin receptors (PRLR), which are present in many organs and tissues. SNP g. $1789 \mathrm{G}>\mathrm{A}$ in PRLR gene leads to amino acid replacement (Gly/Ser) in prolactin receptor which affects the survivability of piglets and reproduction of saws [5]. Mentioned SNPs were found to have a significant effect in certain pig breeds of different selections. The first step of MAS is to see if the SNP has the same allele spread in a certain breed and to evaluate the level of heterozygosity and PIC coefficient to see if the associative study of genetic markers with traits will be relevant.

The aim was to develop genetic markers of productive traits of pigs of Ukrainian Large White pig breed based on population-genetic studies of polymorphisms of RYR1, ESR1 and PRLR genes. Additionally, PCR-PLRF method for SNP genotyping has to be optimized.

Materials and methods. The genetic studies involved the use of blood samples of 200 pigs of Ukrainian Large White of first and second inside breed type, bred at SP «PLEMZAVOD IM.KALININA», Bakhmut district, Donetsk region, Ukraine. DNA from blood samples was extracted using Chelex 100 reagent [3].

DNA amplification with PCR was performed using a programmed thermostat (Table 1) and primer sequence. The restriction analysis using relevant endonucleases was performed according to the manufacturer's instructions (Thermo Fisher Scientific). PCR products were separated using $2 \%$ agarose gel-electrophoresis in $1 \times$ Tris-borate electrode buffer (TBE) for $2 \mathrm{~h}$ at the current of $50 \mathrm{~mA}$ in the electrophoretic chamber.

DNA of plasmid pUC19, hydrolyzed by endonuclease Msp I (Thermo Fisher Scientific), was used as a marker of molecular mass. After electrophoresis, the gel was stained with the solution of ethidium bromide $(10 \mathrm{mg} / \mathrm{cc})$ and the electrophoresis results were documented with the digital camera using the transilluminator.

Allele frequencies, genotype frequencies, polymorphic information content (PIC), and levels of heterozygosity (observed heterozygosity, Ho and expected heterozygosity, He) were calculated with GenAlEx 6.0. software [2]. Analysis of associations between genotypes and meat quality characteristics were performed by one-way ANOVA. 
PCR primers, PRC-RFLP patterns of different alleles of $R Y R 1, E S R 1$ and PRLR genes in pigs of Ukrainian Large White breed

\begin{tabular}{|c|c|c|}
\hline $\begin{array}{l}\text { Gene/ } \\
\text { DNA } \\
\text { marker }\end{array}$ & $\begin{array}{l}\text { Primer structure }\left(5^{\prime} \rightarrow 3^{\prime}\right) / \text { the size of am- } \\
\text { plification fragment }\end{array}$ & $\begin{array}{l}\text { Restriction enzyme, the size } \\
\text { of the fragments after re- } \\
\text { striction }\end{array}$ \\
\hline $\begin{array}{l}R Y R 1 / \\
\text { SNP } \\
\text { g. } 1843 \\
\mathrm{C}>\mathrm{T}\end{array}$ & $\begin{array}{l}\text { F: GTGCTGGATGTCCTGTGTTCCCT } \\
\text { R:CTGGTGACATAGTTGATGAGGTTTG } \\
137 \text { bp }\end{array}$ & $\begin{array}{l}\text { Hha I } \\
\text { CC: } 137 \\
C T: 137,84,5 \\
T T: 84,53\end{array}$ \\
\hline $\begin{array}{l}\text { ESRI } \\
\text { SNP } \\
\text { c. } 1227 \\
\text { C }>\text { T }\end{array}$ & $\begin{array}{l}\text { F: CCTGTTTTTACAGTGACTTTT } \\
\text { ACAGAG } \\
\text { R: CACTTCGAGGGTCAGTCCAATTAG / } \\
120 \mathrm{bp}\end{array}$ & $\begin{array}{l}P v u \text { II } \\
A A: 120 \\
A B: 120,65,55 \\
B B: 65,55\end{array}$ \\
\hline $\begin{array}{l}P R L R \\
\text { SNP } \\
\text { g.1789 } \\
\text { G>A }\end{array}$ & $\begin{array}{l}\text { F: CCCAAAACAGCAGGAGGACG } \\
\text { R: GGCAAGTGGTTGAAAATGGA / } \\
457 \mathrm{bp}\end{array}$ & $\begin{array}{l}\text { AluI } \\
\text { AA: } 124,90,79,77,67,20 \\
A B: 124,110,90,79,77,67,20 \\
B B: 124,110,79,77,67\end{array}$ \\
\hline
\end{tabular}

Research results and discussions. Genetic factors are among the traits that affect productivity, meat quality and resistance to certain diseases. Identification of molecular markers which are related to major genes is a promising approach for improving economic traits and has to be checked in breeding animals.

SNPs genotyping in pig breeds of foreign selection has to be taking into account in terms of avoiding SNPs that are not polymorphic. Same time, the SNPs which allele can cause efficient damage/ defect has to be primarily checked for certain genotype. Such "damaging" SNP g.1843 C $>\mathrm{T}$ is located in RYRl gene, causing significant meat quality defects such as PSE syndrome [8,9]. The homozygous pigs of $\mathrm{T}$ allele are more stress susceptible (porcine stress syndrome) and produce meat of poor PSE quality (pale, soft and exudative) after the slaughtering, which is also the case to some extent in heterozygous animals (with TC genotype). The SNP g.1843 C > T was not polymorphic in ULW-1 and ULW-2 which indicates the absence of unwanted allele T (Table 2). Same time, further genotyping of animals of ULW-1 and ULW-2 has to be continued to eliminate using animals with the mutated RYR-1 within the selection process. Although SNP g.1843 C > T has been reported to be polymorphic in commercial crossbred combinations of Check Landrace, Pietren and Large White and purely bred Check Hampshire. Only two genotypes of the mutation in the RYRl gene were found (CC in 428 and $C T$ in 90 pigs) [6].

Table 2

Genotypes, allele frequencies and heterozygosity for in Ukrainian Large White pig breed SNP g.1843 C > T

\begin{tabular}{|c|c|c|c|c|}
\hline \multirow{2}{*}{ Breed (n) } & \multirow{2}{*}{ allele frequencies } & \multicolumn{3}{|c|}{ Genotype frequencies $\mathbf{H}_{\mathbf{0}} / \mathbf{H}_{\mathbf{e}}$} \\
\cline { 3 - 5 } & & $\mathbf{T T}$ & $\mathbf{T C}$ & $\mathbf{C C}$ \\
\hline ULW-1 & $\mathrm{T}=1,00$ & 1,00 & 0.00 & 0.00 \\
$(102)$ & $\mathrm{C}=0.00$ & $(1,00)$ & $(0.00)$ & $(0.00)$ \\
\hline ULW-2 & $\mathrm{T}=1,00$ & 1,00 & 0.00 & 0.00 \\
$(98)$ & $\mathrm{C}=0.00$ & $(1,00)$ & $(0.00)$ & $(0.00)$ \\
\hline
\end{tabular}

Notes. $H_{o}$-observed heterozygosity; $H_{e}$-expected heterozygosity 
The SNP polymorphisms of ESRI (SNP c.1227 C> T) and PRLR (SNP g. 1789 $\mathrm{G}>\mathrm{A}$ ) genes were polymorphic in the Ukrainian Large White pig breed of different inside breed types inside breed types. Overall, SNP ESR1 c.1227 C> T showed allelic frequencies ranging from 0.31 to 0.47 . Alleles $\mathrm{T}$ and $\mathrm{C}$ had almost equivalent frequency for ULW-1 when C allele was more prevalent in ULW-2 (Table 3). Allele frequency of ULW-1 and ULW-2 led to a high PIC value (over 0.3) which indicates the informativeness of a genetic marker for further linkage studies. Expected $(\mathrm{He})$ heterozygosity values were significantly different from observed heterozygosity (Ho) in ULW-2 according to high $\chi^{2}$ value.

Table 3

Genotypes, allele frequencies and heterozygosity for in Ukrainian Large

White pig breed ESR1 SNP c.1227 C> T

\begin{tabular}{|c|c|c|c|c|c|c|c|}
\hline \multirow{2}{*}{ Breed (n) } & \multirow{2}{*}{$\begin{array}{c}\text { Alle } \\
\text { frequency }\end{array}$} & \multicolumn{2}{|c|}{ Genotype frequency $\mathbf{H}_{\mathbf{0}} / \mathbf{H}_{\mathbf{e}}$} & \multirow{2}{*}{$\chi^{2}$} & \multirow{2}{*}{ F } & \multirow{2}{*}{ PIC } \\
\cline { 3 - 5 } & $\mathbf{C C}$ & $\mathbf{C T}$ & $\mathbf{T T}$ & & & \\
\hline ULW-1 & $\mathrm{C}=0.47$ & 0.21 & 0.51 & 0.28 & 0.059 & -0.024 & 0.374 \\
$(102)$ & $\mathrm{T}=0.53$ & $(0.217)$ & $(0.498)$ & $(0.285)$ & & & \\
\hline ULW-2 & $\mathrm{C}=0.69$ & 0.58 & 0.23 & 0.19 & 20.929 & 0.457 & 0.3363 \\
$(98)$ & $\mathrm{T}=0.31$ & $(0.483)$ & $(0.424)$ & $(0.093)$ & & & \\
\hline
\end{tabular}

Notes. $H_{o}$-observed heterozygosity; $H_{e}$-expected heterozygosity

Consequently, there was a significant drift of Hardy-Weinberg equilibrium which can lead to changes of allele frequencies from one generation to the next of the current breed. Contradictory, in UWL-1 the Ho values didn't significantly differ from He, which shows that SNP ESRI c. $1227 \mathrm{C}>\mathrm{T}$ is in Hardy-Weinberg equilibrium. Being within Hardy-Weinberg equilibrium for a certain mutation means that allele frequencies will stay the same across generations for current SNP and breed. According to Munoz G. [1] studies ESRl c.1227 C> T was highly polymorphic in the ChineseEuropean pig line with allele frequency $\mathrm{C}=0.54$ and $\mathrm{T}=0.46$.

Table 4

Genotypes, allele frequencies and heterozygosity for in Ukrainian Large White pig breed SNP g. 1789 G $>A$ in PRLR

\begin{tabular}{|c|c|c|c|c|c|c|c|}
\hline \multirow{2}{*}{$\begin{array}{c}\text { Breed } \\
\text { (n) }\end{array}$} & \multirow{2}{*}{$\begin{array}{c}\text { Allele } \\
\text { frequency }\end{array}$} & \multicolumn{3}{|c|}{ Genotype frequency $\mathrm{H}_{0} / \mathrm{H}_{\mathrm{e}}$} & \multirow{2}{*}{$\chi^{2}$} & \multirow{2}{*}{$\mathbf{F}$} & \multirow{2}{*}{ PIC } \\
\hline & & GG & GA & $\mathbf{A A}$ & & & \\
\hline $\begin{array}{l}\text { ULW-1 } \\
(102)\end{array}$ & $\begin{array}{l}G=0.37 \\
A=0.63\end{array}$ & $\begin{array}{c}0.30 \\
(0.137)\end{array}$ & $\begin{array}{c}0.13 \\
(0.466)\end{array}$ & $\begin{array}{c}0.57 \\
(0.397)\end{array}$ & 55.715 & 0.732 & 0.358 \\
\hline $\begin{array}{l}\text { ULW-2 } \\
(98)\end{array}$ & $\begin{array}{l}\mathrm{G}=0.39 \\
\mathrm{~A}=0.61\end{array}$ & $\begin{array}{c}0.29 \\
(0.148)\end{array}$ & $\begin{array}{c}0.19 \\
(0.474)\end{array}$ & $\begin{array}{c}0.52 \\
(0.378)\end{array}$ & 35.853 & 0.599 & 0.363 \\
\hline
\end{tabular}

SNP g. 1789 G>A in PRLR in ULW-1 and UWL-2 had similar allele frequencies when A allele was always prevalent (Table 4). PIC of ULW-1 and ULW-2 was very high ( 0.358 and 0.363 , respectively). This level of informativeness is most favorable for undertaking association studies. The observed and expected heterozygosity values were significantly different, which is proven by high $\chi^{2}$ values. It indicates a significant drift of Hardy-Weinberg equilibrium which indicates current SNP to be highly informative for further associative studies. In Tomas A. studies [5] current SNP was 
found to be highly polymorphic in crossbred pigs of Iberian, Landrace and Meishan breeds.

\section{Conclusions:}

1. PCR-PLRF method for determining genotypes of single-nucleotide polymorphisms of RYRl, ESR1 and PRLR genes were optimized for accurate genotyping in pigs.

2. According to the results of population genetic analysis it was established that SNP RYR1 g.1843 C > T was not polymorphic in Ukrainian Large White pig breed in ULW-1 and ULW-2 inside breed types.

3. The possibility of forming reference groups by SNPs ESRI SNP c.1227 C> T and PRLR g. $1789 \mathrm{G}>\mathrm{A}$ in Ukrainian Large White pig breed was proved. SNPs were highly polymorphic and informative by PIC value in ULW-1 and ULW-2 pig breed.

\section{Бібліографічний список}

1. Munoz G., Ovilo C., Estelle J., Silio L., Fernandez A, Rodriguez C. Association with litter size of new polymorphisms on ESRI and ESR12 genes in a ChineseEuropean pig line. Genet Selection and Evolution. 2007. № 39. P. 195-206. DOI : 10.1186/1297-9686-39-2-195.

2. Peakall R., Smouse P. GENALEX 6: genetic analysis in Excel. Population genetic software for teaching and research. Molecular Ecology. 2006. № 6. P. 288-95. DOI : $10.1111 /$ j.1471-6.2005.01155.x.

3. Shen X., Li M., Wang Y., Chen Y., Lin Y., Zhao Z., Que T. Comparison of MPure-12 Automatic Nucleic Acid Purification and Chelex-100 Method. Fa Yi Xue Za Zhi. 2017. № 33. P.168-170. DOI : 10.3969/j.issn.1004-5619.2017.02.013.

4. Stinckens A., Magdenberg K., Luyten T., Georges M., Smet S. The RYRI g. $1843 \mathrm{C}>\mathrm{T}$ mutation is associated with the effect of the IGF2 intron $3 \mathrm{~g} .3072 \mathrm{G}>\mathrm{A}$ mutation on muscle hypertrophy. Animal genetics. 2007. № 38. P. 67-71. DOI : 10.1111/j.1365-2052.2006.01558.x.

5. Tomas A., Casellas J., Ramirez O., Munoz G., Noguera J., Sanchez A. High amino acid variation in the intracellular domain of the pig prolactin receptor (PRLR) and its relation to ovulation rate and piglet survival traits. Journal of Animal Science. 2006. № 84. P. 1991-1998. DOI : 10.2527/jas.2005-664.

6. Vehovsky K., Zadinova K. Stupka R., Cítek J., Okrouhla M., Lebedova N., Sprysl M. Effect of the Ser638Arg variation in the cast gene and causal SNP g.1843C>T in the RYRl gene on carcass traits in crosbreed pigs. Genetika. 2019. № 51. P. 61-68. DOI : 10.2298/GENSR1901061V.

7. Wakchaure R., Ganguly S., Praveen K., Avinash S., Subhash M. Marker Assisted Selection (MAS) in Animal Breeding: A Review. Journal of Drug Metabolism and Toxicology. 2015. № 6. P. 1-4. DOI : 10.4172/2157-7609.1000e127.

8. Wendt M., Bickhardt K., Herzog A., Fischer A., Martens H., Richter T. Porcine stress syndrome and PSE meat: Clinical symptoms, pathogenesis, aetiology and aspects of animal welfare. Berliner und Münchener tierärztliche Wochenschrift. 2000. № 113. P. 173-190.

9. Zhang D., Liu D. Polymorphism of the ESRI $\alpha$, PRLR, LH $\beta$ and RYRI Genes in the Four Pig Populations. Journal of Applied Animal Research. 2010. № 38. P. 73-76.

10. Ващенко П. А. Вивчення м'ясо-сальних якостей свиней великої білої породи при поєднанні генотипів вітчизняної та зарубіжної селекцій. Вісник Полтавської державної аграрної академії. Полтава, 2004. № 1. С. 86-88. 


\section{References}

1. Munoz, G., Ovilo, C., Estelle, J., Silio, L., Fernandez, A., \& Rodriguez, C. (2007). Association with litter size of new polymorphisms on ESR1 and ESR12 genes in a Chinese-European pig line. Genet Selection and Evolution, 39, 195-206. DOI 10.1186/1297-9686-39-2-195

2. Peakall, R., \& Smouse, P. (2006). GENALEX 6: genetic analysis in Excel. Population genetic software for teaching and research. Molecular Ecology, 6, 288-95. DOI : 10.1111/ j.1471-6.2005.01155.x

3. Shen, X., Li, M., Wang, Y., Chen, Y., Lin, Y., Zhao, Z., \& Que, T. (2017). Comparison of MPure-12 Automatic Nucleic Acid Purification and Chelex-100 Method. Fa Yi Xue Za Zhi. № 33. P.168-170. DOI 10.3969/j.issn.1004-5619.2017.02.013

4. Stinckens, A., Maagdenberg, K., Luyten, T., Georges, M., \& Smet, S. (2007). The RYRl g.1843C>T mutation is associated with the effect of the IGF2 intron $3 \mathrm{~g}$. $3072 \mathrm{G}>\mathrm{A}$ mutation on muscle hypertrophy. Animal genetics. № 38. P. 67-71. DOI : 10.1111/j.1365-2052.2006.01558.x

5. Tomas, A., Casellas, J., Ramirez, O., Munoz, G., Noguera, J., \& Sanchez, A. (2006). High amino acid variation in the intracellular domain of the pig prolactin receptor (PRLR) and its relation to ovulation rate and piglet survival traits. Journal of Animal Science, 84, 1991-1998. DOI : 10.2527/jas.2005-664

6. Vehovsky, K., Zadinova, K. Stupka, R., Cítek, J., Okrouhla, M., Lebedova, N., \& Sprysl, M. (2019). Effect of the Ser638Arg variation in the cast gene and causal SNP g.1843C $>\mathrm{T}$ in the RYRl gene on carcass traits in crosbreed pigs. Genetika, 51, 61-68. DOI 10.2298/GENSR1901061V

7. Wakchaure, R., Ganguly, S., Praveen, K., Avinash, S., \& Subhash, M. (2015). Marker Assisted Selection (MAS) in Animal Breeding: A Review. Journal of Drug Metabolism and Toxicology, 6, 1-4. DOI 10.4172/2157-7609.1000e127

8. Wendt, M., Bickhardt, K., Herzog, A., Fischer, A., Martens, H., \& Richter, T. (2000). Porcine stress syndrome and PSE meat: Clinical symptoms, pathogenesis, aetiology and aspects of animal welfare. Berliner und Münchener tierärztliche Wochenschrift, 113, 173-190

9. Zhang, D., \& Liu, D. (2010). Polymorphism of the ESRI $\alpha$, PRLR, LH $\beta$ and RYRl Genes in the Four Pig Populations. J. of Applied Animal Research., 38, 73-76

10. Vashchenko, P. A. (2004). Vyvchennia miaso-salnykh yakostei svynei velykoi biloi porody pry poiednanni henotypiv vitchyznianoi ta zarubizhnoi selektsii [Study of meat and fat qualities of Large White pig breed with a combination of genotypes of domestic and foreign selections]. Visnyk Poltavskoi Derzhavnoi Ahrarnoi Akademii. Poltava, 1, 86-88 [in Ukrainian].

\section{ГЕНЕТИЧНИЙ АНАЛІЗ ВЕЛИКОЇ БІЛОЇ ПОРОДИ СВИНЕЙ УКРАЇНСЬКОЇ СЕЛЕКЦІЇ ЗА ПОЛІМОРФІЗМАМИ ГЕНІВ RYRl, ESRl ТА PRLR}

Олійниченко С. К., Россоха В. І., Бойко О. А., Тур Г. М., Задерихіна О. А., Бровко О. В., Інститут тваринництва НААН.

Маркер-асоиійована селекиія набуває розвитку в украӥнській селекиії тварин, як ефективний інструмент селекиії тварин за бажаними якостями. Генотипування за молекулярними маркерами, які відносяться до ключових для метаболізму генів, є перспективним підходом для поліпшення продуктивних ознак. Однонуклеотидні поліморфізми - це генетичні маркери, які можуть бути пов'язані з проявом продуктивних ознак. Генотипування за SNP необхідно проводити додатково для кожної породи, щчоб визначити, чи є вони поліморфними, а асоціації з 
певними ознаками достовірними. Серед генів-кандидатів, які впливають на експресію продуктивних ознак свиней, особливу увагу привертають гени RYR1, ESRI ma PRLR. Ген RYRl асоиійований з гіпертрофією м'язів та іншими дефектами якості м'яса у свиней. Гени ESRI та PRLR впливають на продуктивність свиней.

SNPs RYRl g. 1843 C> T, ESRI SNP c.1227 C> T ma PRLR g. 1789 G>A привертають все більшу увагу як потенційні маркери для поліпшення продуктивних якостей свиней. Було досліджено поліморфізми у трьох генах (RYR1, ESR1 та PRLR) у великій білій породі свиней різних внутрішньопородних типів (УВБ-1 та УВБ-2). Дослідження проводили на 200 свинях. Генотипування проводили за допомогою методу ПЛР - ПЛРФ. SNP RYR1 g. 1843 C> Т був поліморфним в УВБ-1 ma УВБ-2. ESRI SNP c.1227 C> T ma PRLR g. 1789 G> А виявились високополімо-

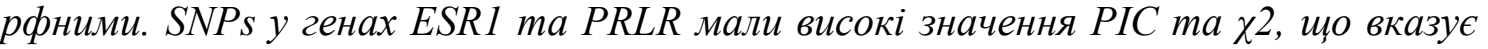
на актуальність подальших асоиіативних досліджень в УВБ-1 та УВБ-2. Інформативність генетичних маркерів у генах ESRI ma PRLR була оптимальною для асоиіативних досліджень в українській великій білій породі свиней.

Ключові слова: SNP, RYR1, ESR1, PRLR, ПЛР-ПЛРФ, українська велика біла порода

\section{ГЕНЕТИЧЕСКИЙ АНАЛИЗ КРУПНОЙ БЕЛОЙ ПОРОДЫ СВИНЕЙ УКРАИНСКОЙ СЕЛЕКЦИИ ИСПОЛЬЗУЯ ПОЛИМОРФИЗМЫ ГЕНОВ RYR1, ESR1 И PRLR}

Олейниченко Е. К., Россоха В. И., Бойко Е. А., Тур Г. Н., Задерихина Е. А., Бровко А. В., Институт животноводства НААН.

Маркер-ассочиированная селекиия получила развитие в украинской селекиии животных, как эффективный инструмент для выбора животных с желаемыми качествами. Генотипирование по молекулярным маркерам, которые относятся к ключевым для метаболизма генам, является перспективным подходом для улучшения продуктивных признаков. Однонуклеотидные полиморфизмы это генетические маркеры, которые могут быть связаны с продуктивными признаками. Генотипирование с использованием SNPS необходимо проводить дополнительно для каждой породы, чтобы определить, являются ли они полиморфными, а ассочичации с определенныли признаками достоверными. Среди геновкандидатов, которые влияют на экспрессию продуктивных признаков свиней, особое внимание привлекают гены RYR1, ESR1 и PRLR. Ген RYR1 ассоииированный с гипертрофией мыши и другими дефектами качества мяса у свиней. Гень ESR1 и PRLR влияют на производительность и опорос свиней.

SNPs RYR1 g. 1843 C> T, ESR1 SNP c.1227 C> T u PRLR g. 1789 G> A привлекают все большее внимание как потенциальные маркеры для улучшения продуктивных качеств свиней. Было исследовано полиморфизмы в трех генах (RYR1, ESR1 и PRLR) в крупной белой породе свиней различных внутрипородных типов (УКБ-1 и УКБ-2). Исследования проводились на 200 свиньях. Генотипирование проводили с помощьюю метода ПЦР - ПДРФ. SNP RYR1 g. 1843 C> T не был полиморфнылм в УКБ-1 и УКБ-2. ESRI SNP c.1227 C> T и PRLR g. 1789 G> А оказались высоко полиморфными. SNP в генах ESR1 и PRLR имели высокие значения PIC и $\chi^{2}$, что указывает на актуальность дальнейших ассоцииативных исследований в УКБ-1 и УКБ-2. Информативность генетических маркеров в генах ESR1 и PRLR была оптимальной для ассоџиативных исследований в украинской большой белой породе свиней первого и второго внутрипородный тип.

Ключевые слова: SNP, RYR1, ESR1, PRLR, ПЦР-ПДРФ, украинская крупная белая порода. 